ISSN:1308-8173

Geliş Tarihi: 08.06.2020
E-ISSN: 1308-8505

Kabul Tarihi: 24.05.2021
YIL: 2021

Online Yayın: 05.08.2021

ÖZGÜN ARAŞTIRMA
Cilt: 36 Sayı: 2 Sayfa: $295-313$

Doi: $10.24988 /$ ije.202136204

\title{
Akademisyen Olmayanlar Açısından Doktora Eğitimi
}

\section{Barış SEÇER ${ }^{1}$}

Özet

Ülkelerin hem araştırmacı işgücü olarak hem de akademik işgücü olarak doktora mezunlarına ihtiyaçları bulunmaktadır. Bu nedenle doktora yapanların sayısının artması önem taşımaktadır. Akademik personel olmadan doktora eğitimine devam eden kişilerle ilgili araştırmaların azlığı dikkat çekmektedir. Çalışmada akademisyen olmadan dışarıdan doktora yapan kişilerin motivasyonları, deneyimleri ve yaşadıkları sorunlar fenomenolojik bir desende nitel bir araştırma ile incelenmiştir. Ege Bölgesinde bulunan iki devlet üniversitesinde doktora eğitimi gören 23 kişiden oluşan örneklemin çoğunluğu akademik kariyerde bulunmak istemektedir. Sosyalleşme konusunda ise kısmen kendilerini alanın parçası hissetmektedir. Son olarak kadroda olmamaktan kaynaklanan ekonomik sorunlar yaşadıkları belirlenmiștir.

Anahtar kelimeler: Doktora eğitimi, Sosyalleșme, Doktora Eğitiminde Sorunlar Jel Kodu: A20, A23

\section{Doctorate Education for Non-Academics}

\begin{abstract}
Countries need doctorate graduates both as a researcher and as an academic labor. For this reason, it is important to increase the number of doctorate students. At the same time, the scarcity of research on people who continue their doctoral education without academic staff is remarkable. In the study, the motivations, experiences and problems of people who have done a doctorate without being an academician have been examined with a qualitative research. The majority of the sample of 23 people who study doctorate at two state universities in the Aegean Region want to pursue an academic career. As for socialization, they feels part of the field. Finally, it was determined that they experienced economic problems arising from not being in the staff.
\end{abstract}

Keywords: Doctorate education, Socialization, Doctorate education problems Jel Codes: A20, A23

\section{GíRiş}

Günümüzde nitelikli işgücü yetiştirme ve yenilikçiliğin geliştirilmesi konusunda üniversitelere önemli roller düşmektedir. Bu bağlamda araştırmacı yetiştirmeyi amaçlayan doktora eğitimi, aynı zamanda işletmelerin yenilikçilik kapasitesi içinde önem taşımaktadır. Ayrıca bilgi toplumu için gerekli olan işgücünün yetiştirilmesinde üniversitelere ve doktora programlarına dikkat çekilmektedir.

Doktora eğitimi ile ilgili yapılan çalışmaların genellikle doktora eğitiminin içeriği ile ilgili olduğu, örneklemin genellikle araştırma görevlileri olduğu ve doktora öğrencilerinin akademik rollerde istihdam edilmesine odaklandığı görülmektedir. Ancak doktora eğitimi görenlerin bir kısmı çalışmamakta, bir kısmı ise akademi dışında çalışmakta ve bu kişilerin doktora eğitimi süresindeki deneyimleri araştırılmaya açık bir konu olarak karşımıza çıkmaktadır.

Çalışmada araştırma görevlisi olmayan bireylerin neden doktora eğitimine başladıkları ve eğitim sürecindeki deneyimlerine ilişkin görüşleri ele alınacaktır. Ayrıca doktora eğitimine ne kadar uyum sağladıkları ve yaşadıkları sorunlar ile ilgili görüşleri araştırılacaktır.

ATIF ÖNERÍsi (APA): Seçer, B. (2021). Akademisyen Olmayanlar Açısından Doktora Eğitimi İzmir İktisat Dergisi. 36(2). 295-313. Doi: 10.24988/ije.202136204

${ }^{1}$ Doç.Dr., Dokuz Eylül Üniversitesi, İktisadi ve İdari Bilimler Fakültesi, Buca / İZMíR,

EMAIL: baris.secer@deu.edu.tr ORCID: 0000-0003-2041-318X 


\section{B. SEÇER}

\section{DOKTORA EĞİTIMİ}

Yazında doktora eğitimi ile öğrencilerin bağımsız araştırmacılara dönüștürüldüğü, çeşitli istihdam şekillerine uyum yeteneği kazandırılmasıyla akademi, endüstri ve meslekte liderlik pozisyonunda çalışmalarının hedeflendiği

belirtilmektedir (Brailsford,2010). Ancak birçok araştırmacı geleneksel doktora programlarının profesyonel gelişim olanaklarından yoksun olduğunu ve işyerlerine uyum sağlama konusunda zorluk yaşayan uzmanlaşmış mezunlar verdiğini ileri sürmektedir (Parada, Peacock,2015).

$\mathrm{Bu}$ durumda doktora eğitimin amaçlarının incelenmesi gereklidir. Avrupa, ABD, Kanada ve Avustralya'da doktora programlarından beklentiler incelendiğinde üç nokta ön plana çımaktadır. İlk beklenti doktora programlarının araştırmalar aracılı̆̆ıyla bilgi birikimine katkıda bulunması ve buna bağlı olarak ikinci beklenti doktora mezunlarının alanlarında önemli bilgi birikimine sahip olmalarıdır. Son olarak ise doktora eğitiminin transfer edilebilir nitelik ve yetkinlikleri geliştirmesi gerektiği konusunda giderek artan bir kabul bulunmaktadır (Bernstein vd., 2014: 6).

Ülkemizde doktora eğitiminin amacı öğrenciye bilimsel araștırma yapma yeteneğini kazandırmak olarak ifade edilmekte ve transfer edilebilir nitelik ve yetkinlikler vurgulanmamaktadır. Örneğin Lisansüstü Eğitim ve Öğretim Yönetmeliği'nin 15. maddesinde, "Doktora programı, öğrenciye bağımsız araştırma yapma, bilimsel problemleri, verileri geniş ve derin bir bakış açısı ile irdeleyerek yorum yapma, analiz etme ve yeni sentezlere ulaşmak için gerekli becerileri kazandırır" șeklinde açılklanmaktadır (Lisansüstü Eğitim ve Öğretim Yönetmeliği, 2016).

Son yıllarda YÖK tarafından doktora eğitimine yön verilmeye çalışıldığı görülmektedir. Örneğin 100/2000 YÖK Doktora bursları ile ülkemizin ihtiyaç duyduğu alanlarda doktoralı insan kaynağı yetiştirilmesi hedeflenmektedir. YÖK doktora burslarını şöyle açıklamaktadır;
"100 / 2000 Programı bu amaca yönelik olarak ülkemizin ihtiyaçları ve gelişim alanları dikkate alınarak uzun ve katılımcı bir yaklaşımla tasarlanmıştır ve geleceğe yönelik etkin bir projedir. Bu program kapsamında ülkemizin öncelikli alanlarına yönelik 100 alanda 2000 doktoralı insan kaynağı yetiştirilecektir. Bu insan kaynaklarının istihdamı ise sadece akademiye yönelik olmayıp, özellikle kamunun ve özel sektörün de gelişimi odaklı süreçlerine de ciddi yararlar sağlayacaktır" (yuzikibinbursu.yok.gov.tr/Sayfalar/HaberDu yuru/100-2000-doktora-projesi-nedir,2020). YÖK'ün doktora bursları ile doktoralıların akademi dışında istihdam edilmesinin amaçlandığı anlaşılmaktadır. Böylece akademi dışından doktora eğitimi yapılması teşvik edilmektedir.

Ülkemizde lisansüstü eğitim istatistikleri incelendiğinde doktora eğitimi açısından hem önemli bir potansiyelin olduğu ama buna karşın ciddi bir açığın da bulunduğu görülebilir. Türkiye'de 2019-2020 öğretim yllı itibariyle toplam yüksek lisans öğrenci sayısı 297.001 iken, doktora eğitimi gören öğrenci sayısı ise 101.242'dür (YÖK, 2020). 2016 yll itibariyle ülkemizdeki araştırmacı sayısı ise yaklaşık 100.000 'dir. Çin, Japonya ve Almanya gibi ülkelerle karşılaştırdığımızda da ülkemizin araștırmacı sayısı bakımından oldukça geride olduğu görülmektedir. Yükseköğretimdeki araștırmacı sayısı da 2015 yllı itibariyle 43.292'dir. Bir başka ifadeyle, ülkemizdeki araştırmacıların yarısına yakını yükseköğretim kurumlarında çalıșmaktadır. Araștırmacı sayısının artırılması ise ancak doktoralı mezun sayısının arttırılması ile mümkün olabilecektir. Dolayısıyla Türk yükseköğretimindeki en önemli sorunların başında lisansüstü eğitimde yeterli sayıda araştırmacı yetiştirilememesinin olduğu açıkça görülmektedir (Günay,2018:76).

Görüldügü üzere ülkemizin gelecekte daha çok doktora mezununa ihtiyacı bulunmaktadır. Bu nedenle çeşitli alanlarda akademi dışından doktora eğitimine devam edenlerin önem taşıdığı görülmektedir. Çalışmada bu kişilerin doktora yapma motivasyonları, kariyer 
yönelimleri, sosyalleşme süreçleri ve yaşadıkları sorunlar ile ilgili görüşleri nitel bir araştırma ile incelenecektir. Böylece akademi dışından doktora yapan kişilerin durumları ile ilgili bir değerlendirme yapılacaktır.

\subsection{Doktora Eğitimine Yönelik Motivasyon}

Yazında doktora eğitiminin riskli bir süreç olduğu belirtilmektedir. Bazı araştırmalar uzun yıllar süren doktora eğitimini yarıda bırakma riskinin yüksek olduğunu göstermekte ve bireylerin sonu belli olmayan bu sürece neden katıldıklarını sorgulamaktadır. Churchill ve Sanders (2007:13), doktoraya başlamanın nedenlerini beş genel başlıkta sınıflandırmıștır: kariyer gelişimi, iş doyumu yetersizliği, kişisel gündem, aktif politik katılım olarak araştırma yapma ve bir meydan okumaya sürüklenme.

Gill ve Hope (2009) ise, doktora eğitimine katılmaya yönelik motivasyonları gösteren beş profil belirlemiştir: geleneksel (akademiye girme), profesyonel gelişim, sürekli gelişim (profesyonel ilerleme), geçiş (yeni bir kariyere girme) ve kendini geliştirme. İlk dört profilin farklı kariyer aşamalarına uygun olduğunu, geleneksel ve profesyonel gelişim profilinin erken kariyer aşamaları ile ilgiliyken, sürekli gelişim ile geçiş profilinin orta ve geç kariyer dönemleri ile ilgili olduğunu ileri sürmektedir.

Brailsford (2010), bir Avustralya üniversitesinden 11 tarih doktora öğrencisi üzerinde yaptığı araştırma ile eğitime başlama kararlarını etkileyen faktörleri belirlemiştir. Buna göre katılımcıların sosyal adalet konuları ile ilgilenmek veya politika olarak araștırma şeklinde kesin bir motivasyonları bulunmamaktadır. Ancak tarih öğrencilerinin doktoraya başlama kararlarını vermelerinde danıștıkları üçüncü şahısların (arkadaşlar, iş arkadaşları, aile üyeleri ve akademisyenler) cesaretlendirici etkisi bulunduğunu belirlemişlerdir.

Ülkemizde doğrudan doktora eğitimi yapma ile ilgili olmasada lisansüstü eğitim yapma amaçlarını inceleyen araştırmalar bulunmaktadır. Araştırmaların örneklemlerinde doktora yapan öğrenciler de bulunmaktadır. Sayan ve Aksu (2005), akademik personel olmadan lisansüstü eğitim yapan bireylerin amaçlarının özellikle kendilerini alanlarında yetiștirmek, akademisyen olabilmek, mesleğinde yükselmek olduğunu belirlemiştir. Baş (2013), öğretmenlerin lisansüstü eğitimden beklentilerini araştırmıştır. Araştırmada öğretmenlerin hemen hemen hepsinde akademik yarar anlamında lisansüstü eğitimden beklentilerinin olduğu görülmüştür. Öğretmenlerin, lisansüstü eğitimi yalnızca mesleki gelişim için değil, aynı zamanda akademik anlamda yükselmek için de talep ettikleri saptanmıștır.

Parada ve Peacock (2015), 12 Avrupa ülkesinde 7561 doktora adayından oluşan örneklemde doktora bittikten sonra hangi alanda çalışmak istedikleri ile doktora eğitiminin akademi ve özel sektörde iş imkânlarını arttırıp arttırmadığı konusunda düşüncelerini araştırmıştır. Bütün ülkelerde çalışmak için akademik kariyer en popüler seçimdir ve bunu takiben akademik olmayan kamu araştırma sektörü ve özel sektör gelmektedir. Ülkelerin çoğunda katılımcıların en az \%50'si akademik olmayan bir sektörde araştırma kariyerini düşünmektedir. Katılımcıların çoğunluğu doktora eğitiminin akademik alanda iş imkanlarını arttırdığını düşündüklerini belirtirken, akademi dışında ise istihdam imkanlarını arttırma konusunda daha olumsuz düşünmektedirler.

Yazında doktora yapılan alana göre de kariyer tercihlerinin şekillenebileceği belirtilmektedir. De Grande vd. (2014), 4878 doktora öğrencisinden oluşan örneklemde endüstride ve diğer akademik olmayan sektörlerde istihdama yönelik tutumları incelemektedir. De Grande vd. (2014:545), doktora öğrencilerinin akademik kariyeri tercih edeceklerini ve akademik olmayan işgücü piyasası tercihlerinin ise araştırma alanına göre farklılaşacağını ileri sürmektedir. Gerçekten mühendislik alanında doktora yapanların yaklașık yarısı $(\% 51,2)$ endüstride bir kariyeri tercih ederken, bu tercih beșeri bilimlerde $(\% 3,9)$ ve sosyal 


\section{B. SEÇER}

bilimlerde $(\% 7,4)$ olarak belirlenmiștir. Kısaca bazı alanlarda doktora yapan öğrencilerin akademik kariyeri daha çok tercih ettikleri ileri sürülebilir.

\subsection{Sosyalleşme Süreci}

Sosyalleşme süreci belirli bir topluma, gruba veya örgüte üyelik için gerekli olan değerlerin, niteliklerin, tutumların, normların ve bilginin benimsenmesi için öğrenme aracılığıyla gerçekleşmektedir. Bir yükseköğretim kurumunda sosyalleşmenin üç temel öğesi olduğu ileri sürülmektedir: a) öğrencilerin eğitim ortamındaki yapıyla etkileşimleri, b) öğrenciler ve öğretim üyeleri arasındaki etkileşim ve c) aynı eğitim programındaki öğrenciler arasındaki etkileşim (Gardner, Gopaul, 2012:65)

Nyquist vd. (1999), tarafından yaplan araştırma sonucunda doktora öğrencilerinin öğretme süreci için sosyalleşmesinin büyük bir ölçüde öğretim üyeleri ile etkileşim içinde olma aracılığıyla ortaya çıktığı belirlenmiștir. Ancak doktora öğrencilerinin gelecekteki rolleri ile ilgili sistematik bir hazırlık yapılmadığı ve kendilerine gelişim süreci ile ilgili yetersiz geribildirim ve akı hocalığı yapıldığı belirtilmektedir.

Görüldüğü üzere doktora öğrencilerinin öğretme faaliyetleri için öğretim üyeleri ile tanışmaları ve görüşmeleri sosyalleşme süreçleri için önemli görülmektedir. Araştırma için sosyalleşme perspektifinde yine öğretim üyeleri ile etkileşim, profesyonel faaliyetlere katılım, araştırma yaparak uygulamalı deneyim ve akademik yayınlara uygun şekilde yazma pratikleri geliştirme vurgulanmaktadır (Weidman,2010:48).

$\mathrm{Bu}$ bağlamda danışmanlar ile ilişkilerin sosyalleşme sürecinde etkili olduğu anlaşılmaktadır. Sezgin (2002) tez yazım sürecinde tez danışmanı ve tez öğrencisi arasındaki ilişkiyi bir tür yetiştiricilik ilişkisine benzetmekte ve bu süreçte deneyimli ve bilgili öğretim elemanlarının formel ve informel olarak önemli rol oynayacaklarını vurgulamaktadır. $\mathrm{Bu}$ bağlamda, lisansüstü eğitim bir yetiştiricilik süreci olarak görülüp öğrenci ile danışmanı arasındaki mesleki ve sosyal etkileşimi etkin kllacak şekilde sürdürülebilir.

Hatta doktora öğrencilerinin eğitimlerinin ilk aşamalarında danışmanları ile daha yapısal ilişkiler kurduklarında, örneğin tarafların rollerinin ne olduğunun tanımlandığı resmi sözleşmeler yapıldığında daha başarılı olacakları ileri sürülmektedir. Örneğin 12 Avrupa ülkesinden 7561 doktora öğrencisinin katıldığı araştırmada, örneklemin çoğunluğu danışmanlarını eğitimleri sırasında destekleyici bulmuştur. Tüm doktora öğrencileri danışmanlarından aldıkları geribildirimi çok yararlı olarak değerlendirmiştir. Geribildirimin yararlı bulunması iyi danışmanlık sağlamanın ve tavisye verecek bir danışmanın olmasının önemini göstermektedir (Parada, Peacock, 2015:601).

Benzer şekilde Karadağ vd. (2018), doktora eğitimini sürdüren Eğitim Fakültesi araştırma görevlileri örnekleminden elde ettikleri bulgularda, danışmanın doktora tez sürecinde kilit rol oynadığı ve bütün süreci olumlu ya da olumsuz şekilde etkileyebilecek bir noktada olduğunu tespit etmişlerdir. Sever ve Ersoy (2017) ise, doktora yapan araştırma görevlilerinin danışmanlarını kendileri için yönlendirici, destekleyici ve öğretici olarak gördüklerini belirlemiştir.

Doktora öğrencilerinin öğretim üyeleri ile etkileşim içinde olmaları ve sosyal ağ geliştirmeleri önemlidir. Ayrıca bilimsel faaliyetlere katılımları sosyalleşme süreçleri için faydalı olabilecektir. Bunun yanısıra dışarıdan doktora yapan öğrencilerin sosyalleşme süreçleri ile ilgili olarak kendilerini akademik alanın parçası olarak hissetme durumları incelenmelidir.

Doktora öğrencilerinin kendilerini akademik alanın bir parçası olarak görmelerinin iyi bir akademik kültüre işaret ettiği belirtilmektedir. Bireyler kendilerini değerli hissettiklerinde, kendilerine ihtiyaç olduğunu düşündüklerinde bulundukları topluluğa bağlılık hissetmektedir. 
$\mathrm{Bu}$ durum akademiye uyarlandığında doktora öğrencileri bilimsel faaliyetlere katıldıklarında alanın parçası olarak hissetmeleri olumlu etkilenmektedir. Emmioğlu vd. (2017), doktora öğrencilerinin alanın bir parçası olma konusunda olumlu hissetmelerini sağlayan durumları şöyle belirlemişlerdir:

- Yayın ve eğitim faaliyetlerinde çalışarak öğrendiklerinde ve katkı sağladıklarını hissettiklerinde,

- Diğerleri tarafından önemli olarak kabul edildiklerinde (danışman, diğer akademisyenler, akranlar ve akademisyen olmayanlar); araştırmacı olarak tasvip edilmek ve saygı görmek güven ve özgüven duygularına neden olmaktadır,

- Katılım sonucu öğrenme ve elde edilen deneyimlerin kariyer profillerini ve umutlarını geliştirdiğini hissetmeleri durumları alanın parçası olmayı hissetmeye yardımcı olmaktadır.

\subsection{Doktora Eğitimi Sürecinde Karşılaşılan Sorunlar}

Yazında yüksek lisans ve doktora öğrencilerinin eğitim sürecinde karşılaştıkları akademik ve genel sorunların incelendiği görülmektedir. Örneğin Sevinç (2001) çalışmasında lisansüstü eğitim sürecinde öğrencilerin karşılaştıkları sorunları belirleyerek sınıflandırmıştır. Bu sorunlar öğretim üyeleri, yabancı dil, danışman ve maddiyat başlıklarında sınıflandırılmıştır.

Sayan ve Aksu (2005:54), ekonomik zorlukların akademik personel olmadan lisansüstü eğitim yapan kişilerin karşılaştıkları en önemli sorun olduğunu belirlemiştir. Nitekim örneklemin \%87'si eğitimlerini sürdürmek için çalışması gerektiğini belirtmiştir. Ayrıca danışmanla iyi iletişim kuramamak, danışmanın yeterli yönlendirmeyi yapamaması gibi sorunlar tespit edilmiștir. Yapılan görüşmeler sonucunda akademik personel olmadan lisansüstü eğitim yapan bireylerin bilimsel etkinliklere katılım konusunda büyük sıkıntı yaşadıkları belirlenmiştir.
Kongrelere katılım konusunda öne sürülen sorunlar zamanlarının yeterli olmayışı, kongrelerden haberdar olamayış ve ekonomik sebepler olarak belirlenmiştir. Bilimsel etkinlikler açısından veriler incelendiğinde en önemli sorun bilimsel çalışmalarda tercih edilmemeleri olarak tespit edilmiștir. Lisansüstü eğitim yapanlar bilimsel çalışmalarda akademik personelin daha çok tercih edildiğini, kendilerinin ikinci planda kaldığını belirtmişlerdir. Kaynak yetersizlikleri ve kütüphanelerden yararlanma zamanlarının yeterli olmayışı ve çalışmaların yayınlanmasındaki zorluklarda önemli problemler olarak vurgulanmaktadır (Sayan, Aksu, 2005:64-65).

Akbulut vd. (2013), doktora tez sürecinde karşılaşılan sorunları eğitim fakültesi örneğinde inceleyen bir araștırma yapmıştır. Mülakatlar sonucunda katılımcıların tez konusu ve tez komitesi belirleme süreçlerinde, danışmanlarının etkisinin önemli rol oynadığı, ancak katılımclların altı aylık rapor sunumlarından yeterince verim alamadıklarına ilişkin veriler elde edilmiştir.. Katılımcılar daha nitelikli tezlerin ortaya çıkabilmesi için tez konusu, tez izleme komitesi vb. seçimlerini kendilerinin yapması ve altı aylık rapor sunumlarında daha sistemli bir yol izlenmesi gerektiği şeklinde önerilerde bulunmuşlardır.

Özmen ve Güç (2013), 10 doktora öğrencisinden oluşan örneklemde karşılaşılan zorlukları ve başa çıkma stratejilerini incelemiştir. Doktora öğrencilerinin en çok danışman, alan, dersler ve zaman yönünden problemler yaşadıkları belirlenmiștir. Öğrencilerin danışmanlar ile iletişime geçme ve onlarla çalışmada yaşadıkları zorluklar mülakatlarda sık sık tekrarlanmıştır. Çalışmada "özel hayat ve ulaşım” gibi zorluklar da tespit edilmiştir. Katılımcıların bir kısmı farklı şehirlerden gelmenin zorluklarına değinmiştir. Ayrıca katılımcılar doktora eğitimi sırasında özel hayatlarından fedakarlık yapmak durumunda kaldıklarını vurgulamıştır.

Golde (2005), araştırma için maddi kaynağın olmamasının daha düşük doktora eğitimi 


\section{B. SEÇER}

tamamlama olasılı̆̆ı ve/veya daha uzun sürede mezun olma şeklinde yansıyabileceğini belirtmektedir. Ülkemizde ise Keçeli ve Duymaz (2017), lisanüstü eğitimi anket ile değerlendirdikleri araştırmada öğrencilerin proje desteklerini yetersiz bulduklarını belirlemiştir.

Doktora eğitimine akademik kariyer, mesleki gelişim gibi farklı motivasyonlarla başlanabildiği belirtilmektedir. Eğitim süresince çeşitli sosyalleşme faaliyetleri ile kendini alanın bir parçası hissetme ve sosyal ă̆ geliștirme süreçleri yaşanmaktadır. Ayrıca eğitim süresince yaşanan sorunlar eğitim sonuçlarını etkileme potansiyeline sahiptir. Çalışmada akademik kadroda olmadan doktora eğitimi yapan kişilerin motivasyonları, deneyimleri ve yaşadıkları sorunlar incelenmektedir.

\section{YÖNTEM}

Çalışmada nitel araştırma yöntemi seçilmiş olup, toplanan veriler MAXQDA 12 programı ile analiz edilmiştir. Araştırma yaklaşımında olgubilim (fenomenoloji) deseni kullanılmıştır. Olgubilim olarak da adlandırılan fenomenoloji "Gerçek nedir?" sorusuna cevap arayan bir yöntemdir. Fenomenoloji yaklaşımın temelini bireysel tecrübeler oluşturmaktadır. $\mathrm{Bu}$ yaklaşımda araștırmacı katılımcının kișisel (öznel) tecrübeleri ile ilgilenmekte, bireyin algılamaları ve olaylara yükledikleri anlamları incelemektedir (Akturan ve Esen, 2008). Çalışmada ele alınan olgu, akademi dışından bireylerin doktora eğitimi sürecidir. Katılımcıların bu duruma ilişkin deneyimleri ve bu deneyimlerin onlardaki yansımaları incelenmiştir.

Akademi dışından doktora yapanların eğitim sürecini incelemek için bir soru formu oluşturulmuştur. Soru formunda 7 adet demografik ve 10 adet açık uçlu soru yer almaktadır. Geçerliği sağlamak için soru formu geliştirilirken ilgili yazın taraması yapılmış, görüşmelerin yazılı dökümleri başka bir araştırmacıya gönderilerek kontrol etmesi istenmiştir. Güvenilirlik açısından ise başka bir araştırmacı tarafından da kodlamalar yapılarak temalar olușturulmuş ve bunlarla karşılaştırmalar yapılarak, düzenlemeler yapılmıştır.

Veriler katılımcılara ulaşma zorluğu nedeniyle elektronik ortamda iletilen soru formları ile toplanmıştır. Eşzamanlı iletişim (Skype vb.) dışında eşzamanlı olmayan iletişim (e-posta gibi) sağlayan araçlardan da veri toplama sürecinde faydalanılmaktadır. Eşzamanlı olmayan bir görüşme yöntemi olarak e-posta kullanımının daha ayrıntılı nitel veri sağlayabileceği veya bireylerin deneyimlerinin ve yaşam hikâyelerinin daha düşünümsel olabileceği yazında belirtilmektedir (James, 2016:281).

\section{1. Örneklem}

Örneklem amaçlı örnekleme yöntemlerinden ölçüt örnekleme yöntemi kullanılarak, akademi dışından doktora eğitimi yapanlar olarak belirlenmiştir. Katılımcılar Ege bölgesinde yer alan 2 devlet üniversitesinde, dışarıdan yani akademik kadroda olmadan doktora eğitimi gören 23 kişiden oluşmaktadır (1 katılımcı mezundur).

Tablo 1: Katılımclara Ait Bilgiler

\begin{tabular}{|c|c|c|c|c|c|c|c|}
\hline Kod & Ciusiyet & Yas & $\begin{array}{l}\text { Medeni } \\
\text { Durum }\end{array}$ & $\begin{array}{l}\text { Dolitora } \\
\text { Așaması }\end{array}$ & $\begin{array}{l}\text { Dohtorada } \\
\text { Geçen Süre }\end{array}$ & $\begin{array}{l}\text { Çalıșma } \\
\text { Durummu }\end{array}$ & Doktora Alamı \\
\hline DRI & Erkek & 30 & Evli & Yeterlilik: & 2 yIl & $\begin{array}{l}\text { K15mi } \\
\text { Süreli }\end{array}$ & Sosyal Bilimiler \\
\hline$\overline{D R 2}$ & Erkelk & 27 & Evli & Tez & 2 yil & $\begin{array}{l}\text { Tam } \\
\text { Zamanl1 }\end{array}$ & Sosyal Bilimler \\
\hline DR3 & Kadın & 29 & Belar & Tez & $25 \mathrm{ygl}$ & Çallıgmayor & Fen Bilimleri \\
\hline DR4 & Kadın & 31 & Belar & Tez & 6 yll & If Anyor & Fen Bilimleri \\
\hline$\overline{\mathrm{DR} 5}$ & Kadın & 30 & Bekar & Yeterlilik: & 2 yl & $\begin{array}{l}\text { Tam } \\
\text { Zamanl1 }\end{array}$ & Sosyal Bilimler \\
\hline$\overline{D R 6}$ & Kadın & 33 & Belkar & Tez & 3 yll & Çalıgmay or & Sosyal Bilimler \\
\hline DR7 & Kadın & 33 & Evli & Tez & $4 \mathrm{yll}$ & Calıgmyor & Fen Bilimleri \\
\hline DR8 & Kadın & 35 & Evli & Tez & 5 ysl & Çalığmiyor & Fen Bilimleri \\
\hline$\overline{\mathrm{DRg}}$ & Kadın & 36 & Belar & Tez & 3 yil & $\begin{array}{l}\text { K15mi } \\
\text { Sureli }\end{array}$ & Sosyal Bilimler \\
\hline DR10 & Kadın & 29 & Belar & Ders & 1 y.l & Callıgmyor & Sosyal Bilimler \\
\hline DR11 & Erkek & 40 & Evli & Merun & & \begin{tabular}{l|} 
Tam \\
Zamanl1
\end{tabular} & Sosyal Bilimler \\
\hline DR12 & Erkek & 35 & Evli & Tez & 5 yil & $\begin{array}{l}\text { Tam } \\
\text { Zamanl1 }\end{array}$ & Sosyal Bilimler \\
\hline DR13 & Kadın & 27 & Belar & Ders & 1 yil & Çalığmyor & Sosyal Bilimler \\
\hline DR14 & Erkek & 26 & Belkar & Tez & 3 ysl & $\begin{array}{l}\text { Tam } \\
\text { Zamanl1 }\end{array}$ & Sosyal Bilimler \\
\hline DR15 & Erkek & 27 & Belarar & Ders & 1 yll & Iq Anyor & Sosyal Bilimler \\
\hline DR16 & Erkek & 28 & Belar & Ders & 1 yil & $\begin{array}{l}\text { K1smi } \\
\text { Süreli } \\
\end{array}$ & Sosyal Bilimler \\
\hline DR1? & Erkek & 31 & Evli & Ders & 1 yil & Çalığmyor & Sosyal Bilimler \\
\hline DR18 & Erkek & 34 & Bekar & Tez & $4 \mathrm{yll}$ & \begin{tabular}{l|} 
Tam \\
Zamanl1
\end{tabular} & Sosyal Bilimler \\
\hline DR19 & Erkek & 28 & Belar & Ders & 1 yil & Çalışmayor & Sosyal Bilimler \\
\hline DR20 & Erkek & 32 & $\overline{\text { Evli }}$ & Tez & 3 yyl & Tam & Sosyal Bilimler \\
\hline DR21 & Erkek & 35 & Evli & Tez & $4 \mathrm{yll}$ & $\begin{array}{l}\text { Tam } \\
\text { Zamanl1 }\end{array}$ & Sosyal Bilimler \\
\hline DR22 & Erkelk & 28 & Belar & Ders & 1 yil & Çallşmy or & Sosyal Bilimler \\
\hline DR23 & Kadın & 31 & Belar & Tez & 7 yll & Çalıgnuyor & Sosyal Bilimler \\
\hline DR24 & Kadın & 29 & Bekar & Tez & 2 ysl & If Anyor & Sosyal Bilimler \\
\hline
\end{tabular}

Örneklem 13 erkek ve 11 kadın doktora öğrencisinden oluşmaktadır. Öğrencilerin 9'u evli, 15'i bekardır. Katılımcıların 14 tanesi tez, 7 tanesi ders ve 2 tanesi yeterlilik sinavı 
aşamasındadır. 11 katılımcı çalıștığını (8'i tam zamanlı, 3'ü kısmi süreli), 10 katılımcı çalışmadığını ve 3 katılımcı ise iş aradığını belirtmiştir. Katılımcılar ortalama 31 yaşındadır (Standart Sapma=3,52) ve doktora eğitiminde bulunma süreleri ise ortalama 31 aydır. Katılımcıların büyük çoğunluğu sosyal bilimler alanında doktora eğitimi görmektedir (20 kişi sosyal bilimler, 4 kişi fen bilimleri).

\subsection{Veri Analizi}

Olgubilim araştırmalarında veri analizi, yaşantıları ve anlamları ortaya çıkarmaya yöneliktir. Bu amaçla yapılan içerik analizinde verinin kavramsallaştırılması ve olguyu tanımlayabilecek temaların ortaya çıkarılması çabası vardır. Sonuçlar betimsel bir anlatımla sunulur (Yıldırım ve Şimşek, 2005). Araştırmada elde edilen veriler içerik analizi ile incelenmiştir. İnceleme sırasında katılımcıların cevaplarından yorumlama ve çıkarımlarda bulunma yolları ile analiz yapılmıştır.

Verilerin analizinde şu işlem basamakları takip edilmiştir. İlk önce görüşme formları her bir katılımcı için MAXQDA programına işlenmiştir. Kayda değer cevapların incelenmesiyle kodlar oluşturulmuş; oluşturulan kodlardan benzer özellikler gösterenler birlikte düşünülerek üst kategorilere (tema) ulaşılmıştır. Verilerden olușturulan kod ve temalardan hareketle yapılan yorumlar betimsel bir anlayıșla verilmiștir.

\subsection{Bulgular}

Soru formlarının değerlendirilmesinde MAXQDA 12 programından yararlanılmıştır. Buna göre akademi dışından doktora eğitimi yapanların görüşmelerinden elde edilen verilerle ilgili 12 ana tema ve 58 alt tema belirlenmiştir. Bu temalar altında 291 kodlama yapılmıştır. Böylece akademi dişından doktora yapan kişilerin deneyimleri belirlenmeye çalışılmıştır. Ana tema ve alt temalara ilişkin kodlama ayrıntıları Ek 1'de görülebilir.

Çalışmada ana temalar ve alt temalar doktora eğitimine yönelik motivasyon, sosyalleşme süreci ve sorunlar başlıklarında incelenecektir. Doktora eğitimine yönelik motivasyon başlığ neden doktora yapıldığını ortaya çıkarmayı amaçlamaktadır.

\subsubsection{Doktora Eğitimine Yönelik Motivasyon}

\section{Doktora Eğitiminin Amacı}

Dışarıdan doktora eğitimi yapan kişilere doktora yapma amaçları sorulmuştur. Amaçlar "akademik kariyer", "kendini geliştirmek", "daha iyi kariyer", "araștırma yapmak" ve "alana katkıda bulunmak" şeklinde beş alt temada sınıflandırılmıştır (Şekil 1). En fazla kodlama yapılan alt tema "akademik kariyer" olarak belirlenmiştir.

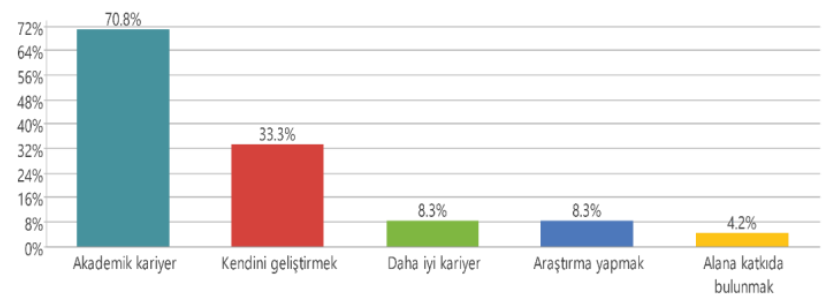

Şekil 1: Doktora Eğitiminin Amaçları Alt Temaları (\%)

Örneğin akademik kariyer alt temasında DR6 kodlu katılımcl, "Íktisat alanında doktora eğitimi yapıyorum ve mezun olduktan sonra akademisyen olarak çalışmak istiyorum. Aslında bunun ötesinde bu alan ile ilgili çalışma yapmayı seviyorum ve başka bir şey yapmayı hiç düşünmedim" şeklinde amacını belirtmektedir. DR13 kodlu katılımcı ise, "Lisansı bitirdiğimden beri akademik kariyer yapmayı istedim ve bunu kendime kariyer hedefi edindim. Doktora eğitimi ise, benim bu hedefe ulaşmama katkı sağlayacak bir basamak işlevi görüyor" ifadeleriyle uzun zamandan beri hedefinin akademik kariyerde yer almak olduğunu belirtmektedir.

"Kendini geliştirmek" ikinci sırada bulunan alt temadır. Bu temada çalışan katılımcıların iş hayatına yönelik ifadeleri dikkat çekmektedir. Örneğin DR21 kodlu katılımcı görüşlerini, "Proje ve sunum çalışmaları ile kurumsal iş hayatına yönelik gelişim, iş arkadaşlarım uyumlu çalışma yönünde kendimi geliştirme firsatı buluyorum" şeklinde ifade ederken, DR11 "Lisans eğitimi aldığım alanda faaliyet gösteren bir kurumda aldığım görev dolayısıyla, 


\section{B. SEÇER}

bu görevi yerine getirirken ihtiyaç duyduğum yetkinlik ve bilgi birikimini geliştirmek" ifadeleriyle doktora eğitiminin çalışma yaşamında kendilerini geliștirmeye olan katkısını vurgulamaktadır. Çok az vurgulanan diğer alt temalardan biri "daha iyi kariyer" iken diğer iki alt tema "bilimsel araştırma yapma" ve "alana katkıda bulunma” șeklindedir.

\section{Doktora Eğitiminin Katkıları}

Doktora eğitiminin kişilere yaptığı katkılara yönelik algılamalar eğitime devam etme konusunda önem taşımaktadır. Doktora eğitiminin kişilere yaptığı katkılar "bilgi düzeyinin artması", "analiz becerilerinin artması", "farklı bakış açıları kazanmak", "başarma hissi", "daha yüksek gelir" ve "iş imkanı" şeklinde altı alt temada sınıflandırılmıştır (Şekil 2). En fazla vurgulanan alt tema "bilgi düzeyinin artması" doktora eğitiminin amaçları ile paralellik göstermektedir.

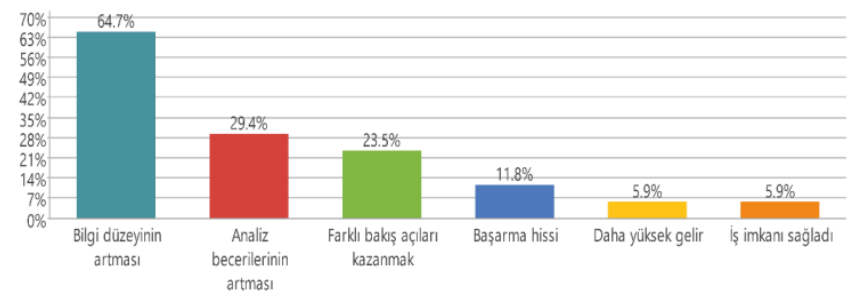

Şekil 2: Doktora Eğitiminin Katkıları Alt Temaları (\%)

DR19 kodlu katılımcl, "Vizyonumun gelişimi ve alanımla ilgili bilgi birikimi sağlaması" șeklinde düşüncelerini ifade ederken, DR18 ise "Sokrates'in "Bildiğim tek şey hiçbir şey bilmediğimdir" sözünü doktora yaparken daha çok özümsemeye başladım. Insan okudukça bir şeyler öğrendikçe ne kadar az şey bildiğinin farkına varıyor. Doktora eğitimi beni bilimsel çalışma sistemine yönlendirmesinin yanında, kişisel gelişimime de katkı sağlayarak her zaman yeni şeyler öğrenmem gerektiği konusunda beni motive etmektedir" şeklinde düşüncelerini aktarmaktadır.

Analiz becerilerinin artması doktora eğitiminin amaçları arasında gösterilmektedir. Daha önce ilgili yönetmelikte analiz etme yeteneğinden bahsedilmiști. Katılımcıların bu konuyu vurgulamaları bilimsel araştırma mantığına sahip olduklarını göstermektedir. Örneğin DR15 kodlu katılımcı, "Akademik araştırma ve analiz etme kabiliyetimi olumlu yönde etkilediğini düşünüyorum" ifadelerini kullanırken, DR11 "sorunları sistematik yaklaşımla çözüme kavuşturma noktasında önemli katkılar sağlamıştır" şeklinde görüşlerini bildirmektedir.

Farklı bakış açıları kazanmak, yine genel doktora eğitiminin amaçları arasında yer alan bir konudur. DR9 rumuzlu katılımcl, "Ufkumu genişletti, bilgilerimi geniş bir perspektife koymama yardımcl oldu, kendimi geliştirebilmem için makale, araştırmacı, yapılan kurslar, konferanslar vs. konusunda yol gösterici oldu. Tam öğrenemesem de ekonometriye giriş yapmış oldum" ifadeleriyle durumu açıklamaktadır.

Ayrıca DR2 kodlu katılımcı "başarmanın verdiği hazzı sağlaması" ifadesiyle başarı güdüsüne işaret etmektedir. Bunun dışında bir katılımcı doktora sayesinde daha yüksek gelir elde ettiğini, başka bir katılımcı ise iş bulduğunu belirtmiştir.

\section{Doktora Eğitiminin Kariyer Hedeflerine Etkisi}

Kariyer hedeflerine etki için "hedeflerime uygun", "bakış açımı genişletiyor" ve "özel sektörde kariyere etkisi yok" şeklinde alt temalar belirlenmiştir (Şekil 3). En çok kodlama yapilan alt tema "hedeflerime uygun" katılımcıların çoğunluğu akademisyen olmak istediği için doktora eğitiminin kariyer hedeflerine uygun olduğu değerlendirilmesine neden olmaktadır. Doktora eğitimi akademik kariyerin en önemli şartı olarak görülmektedir.

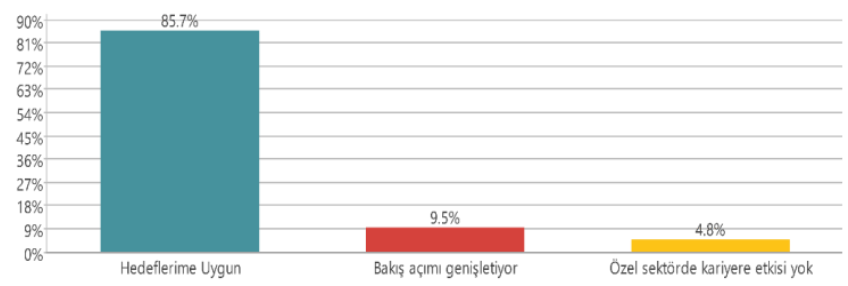

Şekil 3: Doktora Eğitiminin Kariyer Hedeflerine Etkisi Alt Temaları (\%) 
DR8 kodlu katılımcl, "İnsan sevdiği işi yapmalı düsturuyla burada olduğum için, iyi bir akademik kariyer iyi bir doktora ile başlar diye düşünüyorum. Bu açıdan kariyerim için doktora eğitimim oldukça önemli" şeklinde kariyer hedefine uygun olduğunu belirtmektedir. DR13 kodlu katılımcı ise, "Söz ettiğim gibi, lisanstan beri akademisyen olmak üzerine bir kariyer planlaması yaptım. Doktora eğitimine başlamak ise beni bu hedefe bir adım daha yaklaştırdı diye düşünüyorum. Tabii ki doktora bittiğinde hedefime ulaşamamış olma ihtimalimin çok yüksek olduğunun da farkındayım ama hiç değilse hedeflerim doğrultusunda attığım bir adım olduğu için mutluyum ve ilerisini çok düşünmemeye çalışlyorum" ifadelerini kullanmaktadır.

İkinci alt tema "bakış açımı genişletiyor" doktora eğitiminin amaçları arasındadır. DR3 kodlu katılımcı, "Bakış açımı daha fazla genişletmesi nedeniyle olumlu yönde etkiliyor" şeklinde düşüncesini belirtmiştir. Tam zamanlı olarak çalışan bir katılımcl ise doktora eğitiminin özel sektörde kariyer hedeflerini etkilemediğini belirtmiştir.

Doktora Tezinin Kariyere ve İş Bulmaya Etkisi

Katılımcılara doktora tezinin kariyer ve iş bulma etkisi konusundaki düşünceleri sorulmuştur. Katılımcıların büyük çoğunluğu akademik kariyerde yer almak istediği için en çok kodlama "akademik kariyeri olumlu etkiler" alt temasında yapılmıştır.

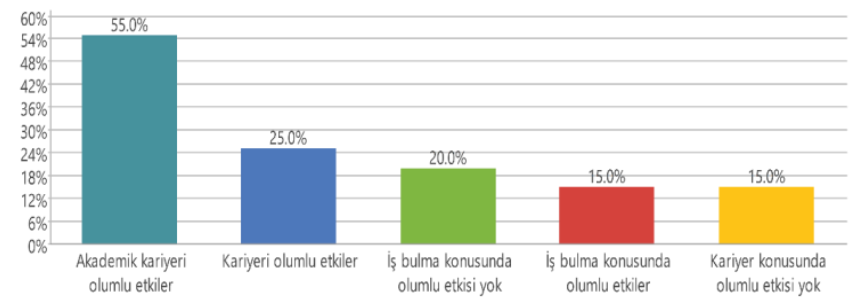

Şekil 4: Doktora Tezinin Kariyere ve İş Bulmaya Etkisi Alt Temaları (\%)

DR6 kodlu katılımcı, "Finansal iktisat alanı ile ilgili bir tez yazmayı düşünüyorum. Yazacağım tez konumu daha belirlemedim ancak seçeceğim tez konumun benim kariyerim açısından önemli olduğunu düşünüyorum. Tez konumun ilgili literatüre katkı yapacak bir araştırmayı içermesi kadro bulabilmemi kolaylaștırabilir" ifadeleriyle literatüre katkı sağlayan tez konusunun akademik kariyer için önemli olduğunu belirtmektedir. DR20 rumuzlu katılımcl ise, "Akademik kariyer hedefime ulaşabilmemin tek yolu doktora tezimi savunmaktan geçiyor. Bu tezin bana başkaca iş alanları açıp açmayacağı konusunu çok irdelemedim ayrıca sevdiğim bir alanda tez yazlyor olmaktan elbette memnunum" şeklinde düşüncelerini belirtmiştir.

Tam zamanlı olarak çalışan DR21, "Çalışacağım tez konusu olan "Katılım Bankacılığı" çalışmaları ile bankacılık sektöründeki gelişmeleri öngörüp, tez çalışmalarım doğrultusunda Katılım Bankacılığına ilişskin bilgi birikimimi artırıp, ülkemizde katılım bankacılığının artan potansiyeli paralelinde kariyer hedeflerimi gerçekleştirebilmek" biçiminde görüşlerini belirtmiştir. Doktora tez konusunun kariyer hedefleri ile doğrudan ilişki olacağını belirtmiştir.

$\mathrm{Bu}$ alt temalar dışında doktora tezinin iş bulma konusunda olumlu etkisi olmayacağl görüşleri de dikkat çekmektedir. Katılımcılar doktora tezlerinin çok spesifik konularda olduğunu belirtmekte ve iş bulma konusunda yararı olmayacağını düşünmektedir. Örneğin DR8, "Akademik çalışmalar dışında doktora tezimin piyasada iş bulmama faydası olacağını sanmiyorum. Birçok doktora tezinde olduğu gibi oldukça spesifik bir konu üzerine çalışıyorum ve piyasanın dolaylı olarak ihtiyacını karşıllyor olsa da talep oluşturacağını sanmıyorum. Iş̧ hayatına atılmak zorunda kalırsam bir șeylere tekrar sıfırdan başlamam gerektiğinin farkındayım" şeklinde durumu açıklamaktadır.

Az sayıda katılımcı ise doktora tezlerinin iş bulma konusunda olumlu etkisi olabileceğini düşünmektedir. Örneğin DR1 kodlu katılımcı, "Üniversitede olmasa bile banka veya borsa gibi yerlerde de pozitif etki yapacağını düşünmekteyim" şeklinde düşüncelerini dile getirirken, DR3 kodlu katılımcı "Çalıştığım tez konusu bilime ve endüstriye katkı sağlayacak bir tez konusu olduğundan, gerek akademik kariyer, 


\section{B. SEÇER}

gerek özel sektörde oldukça katkısı olacağına inanıyorum" ifadelerini kullanmaktadır.

\subsubsection{Sosyalleşme Süreci}

Danışmanın Etkisi

Katılımcılara doktora tez danışmanının mesleki ve akademik kariyer üzerindeki etkisi konusunda düşünceleri sorulmuştur. Danışman etkisi "destekleyicidir", "bilimsel gelişimime katkı sağlıyor" ve "akademik destek yetersiz" șeklinde üç alt temada toplanmıştır. Görüldüğü üzere alt temaların çoğunluğu danışmanlık ile ilgili olumlu algılamalara işaret etmektedir. Örneğin DR3 kodlu katılımcl, "Danışmanım mesleki ve akademik kariyer üzerinde her zaman destekleyicidir. Gerçekleştirmek istediğim çalışmaları dinler, uygulanabilecek aşamalarda yönlendirmeler yapar, gerekli iletişimleri kurmama yardımcı olur. Doktora sürecimi sürdürmemde birçok açıdan olumlu etkisi vardır" ifadeleriyle danışmanının destekleyici olduğunu vurgulamıştır.

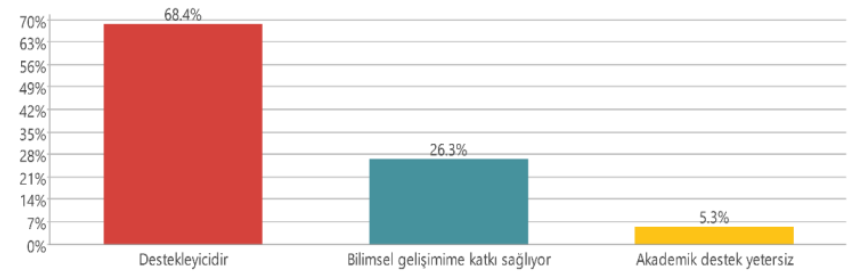

Şekil 5: Danışmanın Etkisi Alt Temaları (\%)

Diğer olumlu alt tema için DR1 kodlu katılımcının düşünceleri örnek verilebilir: "Tez danışmanımın bilimsel olarak daha iyi yetişmem üzerindeki etkisi gerçekten çok iyi". Olumsuz görüşleri olan tek bir katılımcı bulunmaktadır. DR8 rumuzlu katılımcl, "Ancak akademik anlamda destek gördügümü söyleyemem. Zaten doktorada kimse size bir şey öğretmez siz gider sorunun cevabinı bulursunuz, alırsinız ya da bazen alamazsınız" ifadeleri aynı zamanda akademik sosyalleşme sorunları yaşandığına işaret etmektedir.

Sosyal Ağ Geliştirme ve Alanın Parçası Olma

Dışarıdan doktora eğitimine devam eden katılımcılara sosyal a ğ geliştirme ile ilgili düşünceleri ile ilgili ifadelerin yarıya yakını "sosyal ağ geliștiremiyorum" alt temasındadır
(Șekil 6). Bu durum akademik sosyalleșme açısından yetersizlikler olduğunu göstermektedir. Katılımcılar dersler bitince okula gidişlerin azalması ve sadece danışman ile etkileşimde bulunmak gibi noktalara değinmektedir. Katılımcıların bazı ifadeleri şöyledir:

"Okulda olmamanın ve evden çalışmanın faydası olduğu kadar zararı da var. Bunun en başında da hocalarımla ya da diğer akademisyenlerle sık sık görüşememek geliyor. Dersler bitince ne yazık ki biraz kopuşoluyor" (DR9)

"Yeterli etkileşim sağladığımı düşünmüyorum. Akademik topluluğun bir parçası olmaya çalışıyorum. Ancak bu konu da hocalarında biraz destekleyici davranması gerektiği kanaatindeyim" (DR4).

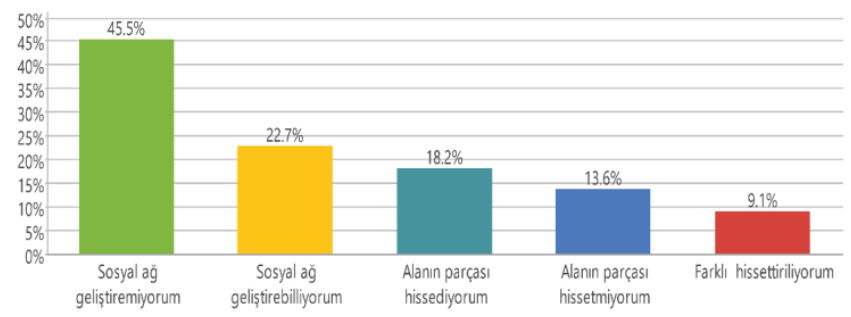

Şekil 6: Sosyal Ağ Geliştirme ve Alanın Parçası Olma Alt Temaları (\%)

İkinci alt tema ise sosyal ağ geliştirebildiğini düşünenlerin görüşlerinden oluşmaktadır. DR8 kodlu katılımcı düşüncelerini şöyle belirtmektedir:

"Elimden geldiğince hem akademik sosyal ağları kullanarak hem konumla ilgili bilinen isimlerle birebir iletişime geçmeye çalışarak bu topluluğun bir parçası olmaya çalışıyorum. Biliyorum ki bir şeyler ürettikçe onlar tarafindan ciddiye alınıp diyaloglara daha fazla dahil edileceğim"

Tam zamanlı olarak çalıșan DR21 ise, "Üniversitede gerek danıșman hocam ve gerekse de ders hocalarıma 7/24 ulaşabilmekteyim, ders programı ve proje çalışmalarını koordineli olarak gerçekleştirme firsatı buluyorum. Düzenlenen etkinliklerle diğer öğrenci arkadaşlarımla ve akademisyenlerle bir araya gelip, paylaşımda bulunma firsatı buldum. Üniversitemizce ticaret odası ve diğer sivil 
toplum örgütlerince ortaklaşa düzenlenen seminerlere, konferanslara hocalarımızca katılımımız sağlanıp bu platformlarda kendimizi ifade edebilme firsatı sunulmaktadır" șeklinde görüşlerini ifade etmektedir.

Katılımcılara doktora yaptıkları alanın bir parçası olarak hissedip hissetmedikleri sorulmuştur. Bir katılımcı akademik normlara uyum gösterdiğini ve akademisyenler ile etkileşim içinde olduğunu şu ifadelerle belirtmiştir: "Özellikle kendi bölümümdeki hocalarım-arkadaşlarım ve firsat buldukça üniversitelerden kişiler ile etkileşim kuruyorum. Kendimi genel kültür, akademik birikim ve diğer normlar açısından akademik topluluğun hali hazırdaki bir parçası olarak görüyorum" (DR2).

DR1 kodlu katılımcı ise, "Sempozyum, kongre ve konferanslara katılmamın bir diğer sebebi de, kendi alanımla ilgili akademisyenlerden ve profesyonellerden oluşan çevremi genişletmektir. Kendimi Ekonometri alanının küçük de olsa bir parçası olarak kabul ediyorum" ifadeleriyle düşüncelerini belirtmiştir.

Alanın parçası olarak hissetmeyenler ise çok çalışmak gerektiğini ve kadro olmadığı için alanın parçası olamadıklarını ileri sürmektedir. Kadro konusu sorunlar ile ilgili alt temalarda yoğun şekilde vurgulanmıştır. İlgili ifadeler şöyledir:

"Henüz böyle bir topluluğun parçası olduğumu düşünmüyorum. Böyle bir topluluğun parçası olmak için, gerçekten çalışıp hakkını vermek dışında çok daha fazla şey yapmam bekleniyor" (DR13).

"Alanım ile ilgili akademisyenler ile sosyal ă̆ geliştirmekle birlikte, bu sosyal ağ seviyesinin orta seviyelerde olduğunu, henüz kendimi akademik bir topluluğun parçası olmadığımı düşünüyorum. Bu düşüncemin temel nedeni, onca çabama rağmen henüz akademik kadroya yerleşememem" (DR23).

Sosyal ağ geliştirme ve alanın parçası olma konusunda bazı katılımcılar dışarıdan doktora yapanlar olarak doktora yapan akademik personelden farklı hissettirildiklerini belirtmișlerdir. Örneğin DR3 kodlu katılımcl düșüncelerini șöyle ifade etmektedir: "Ancak akademik toplulukta genel olarak akademik kadroya sahip bireyler ile aramızda bir farkın olduğunu hissettirildiğini düşünüyorum". Bu ifadeler ayrımcllı düşüncesini akla getirmektedir. Ancak katılımcllar tarafından çok az vurgulanan bir görüş olarak tespit edilmiştir.

\section{Bilimsel Yayınları Takip Etme}

Katılımcıların neredeyse tamamı bilimsel yayınları takip ettiklerini belirtmektedir. Daha önce belirtildiği üzere katılımcıların çoğu akademik kariyeri hedeflemektedir. Dolayısıyla bu hedefin bir parçası olarak yayınları takip etmek durumunda oldukları ileri sürülebilir.

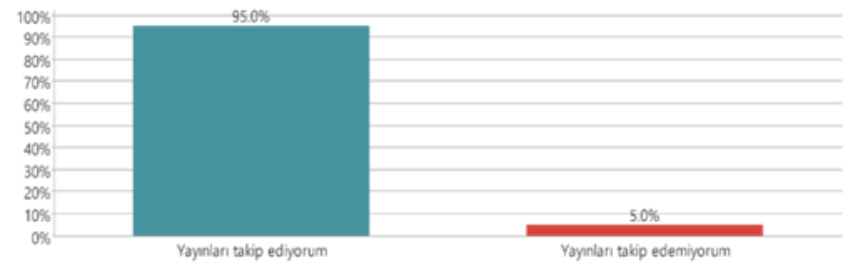

Şekil 7: Bilimsel Yayınları Takip Etme Alt Temaları (\%)

Sadece bir katılımcı iş yoğunluğu nedeniyle yayınları takip edemediğini şöyle belirtmiștir: "Yoğun iş temposu nedeniyle çalışma yaptığım alanla ilgili bilimsel yayınlar takip etme konusunda sıkıntı yaşıyorum" (DR12).

Bilimsel Faaliyetlere Katılım

Bilimsel yayınların takip edilme oranındaki yüksek düzeyin bilimsel faaliyetlere katılım konusunda göreceli olarak düștüğü görülmektedir. Ancak yine de önemli bir çoğunluk bilimsel faaliyetlere katıldıklarını belirtmektedir (Şekil 8).

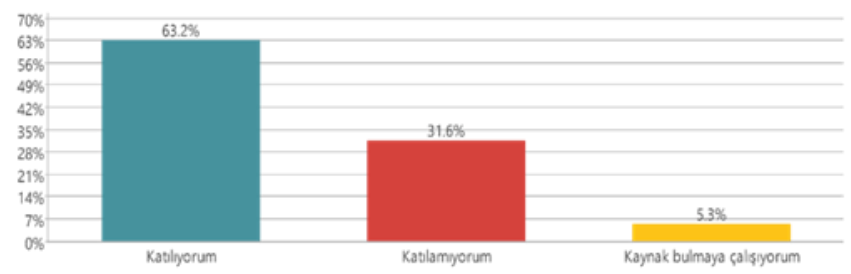

Şekil 8: Bilimsel Faaliyetlere Katılım Alt Temaları (\%)

Bilimsel faaliyetlere katılamadıklarını ve kaynak bulmaya çalıştıklarını ifade edenlerde 


\section{B. SEÇER}

bulunmaktadır. Bilimsel faaliyetlere katılamama çalışma, sağlık sorunları ve kaynak bulamama gibi nedenlere bağlanmıştır.

Yayın Baskısı Hissetme

Bilimsel yayın akademik alanın parçası olmanın en önemli göstergelerinden biri olarak kabul edilebilir. Katılımcılar yayın baskısı hissetme konusunda "baskı hissediyorum", "baskı hissetmiyorum" ve "içsel bir baskı hissediyorum" alt temalarında görüşlerini belirtmektedir. "Baskı hissediyorum" ve "içsel bir baskı hissediyorum" alt temaları birlikte alındığında katılımcıların çoğunluğunun yayın yapma baskısı hissettikleri söylenebilir.

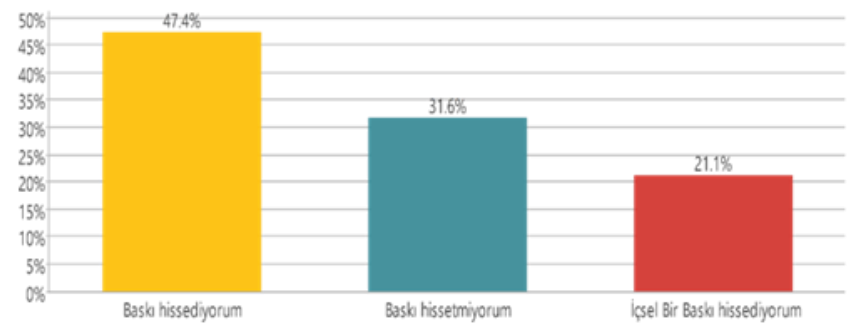

Şekil 9: Yayın Baskısı Hissetme Alt Temaları (\%)

Yayın yapma baskısı hissetme durumunun temel olarak akademik kariyer yapma hedefinden kaynaklandığı söylenebilir. Yayın yapma baskısı ile ilgili DR22, "Kesinlikle üzerimde yayın yapma baskısı hissediyorum. Üzerimdeki bu basklyı da doktoradan arkadaşlarıma yönlendirerek onlarl, birlikte ortak yayın yapmaya zorluyorum. Bu konuda da yılsonuna kadar iki arkadaşımla ayrı ayrı iki farklı konu üzerine çalışma yapmayı planlıyorum" ifadeleriyle yayın baskısı ile başa çlkmak için bir strateji geliştirdiğini açılklamaktadır.

Yayın baskısı hissedenler ayrıca kendiliklerinden veya içsel yayın baskısı hissedenler olarak ayrı bir alt temada da değerlendirilmiștir. Bu alt temada bir zorlama hissetmeksizin gelişimleri için kendiğilinden yayın yapma isteğinden söz edilmektedir. Örneğin DR2 "Sadece üretken olmak adına içsel bir yayın yapma baskısını hissediyorum. Bunun dışsal dayatma ile doğrudan bir ilgisi yok" şeklinde durumu belirtmektedir.
Yayın baskısı hissetmeyen katılımcılar ise genellikle akademi dışından olduklarını, çalıştıklarını belirtmektedir. Sadece DR1 kodlu katılımcl, "Bilimsel makale yayınlama konusunda pek baskl hissetmiyorum. Tekrar veya benzeri çalışmalardan ziyade daha az çalışılan alanlarda ve alanında iyi sayılan (etki faktörü (impact factor) dergilerde yayın yapmak istiyorum" şeklinde yayın baskısı hissetmediğini, daha çok nitelikli yayın yapma konusunda istekli olduğunu belirtmektedir.

\subsubsection{Karşılaşılan Sorunlar}

Akademik Alandaki Sorunlar

Katılımcılardan akademik yaşamlarında karşılaştıkları sorunları açıklamaları istenmiștir. İlk alt tema "kadro olmaması"dır. Diğer alt temalar "eğitim yetersizlikleri", "maddi kaynak bulamama", "tez için veri ve kaynak bulma sorunları", "burs olmaması", "mobbing", "akademik çalışmalara katılamamak" ve "idari sorunlar" olarak belirlenmiştir (Şekil 10).

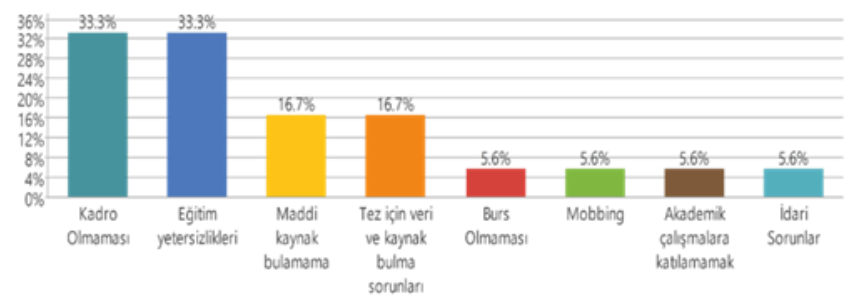

Şekil 10: Akademik Alandaki Sorunlar Alt Temaları (\%)

Katılımcıların akademik kariyer beklentisi ile doktora eğitimi yaptıkları belirtilmişti. Dolayısıyla kadrolarının bulunmaması akademik anlamda bir sorun olarak görülmektedir. DR23 kodlu katılımcl, "Önerim doktora yeterlilik aşamasını geçmiş olan öğrenciler için ayrı bir kadro açılarak üniversitelerde çalışmalarına imkan sağlanması, doktora mezunu olanların ise herhangi bir iş bulma kaygisı yaşamadan akademik alana kazandırılmasının desteklenmesi" ifadesi ile kadro sorunu konusunda önerilerde bulunmaktadır.

Bir katılımcı ise çok fazla kadro başvurusunda bulunduğunu ve kadro alımlarında liyakata 
dikkat edilmediğini belirtmektedir. Alınacak kişinin önceden belli olduğunu ve kadro için referans gerektiğini ifade etmektedir.

İkinci alt temada eğitim ile ilgili yaşanan sorunlar dile getirilmiştir. İki katılımcı seçmeli dersler ile ilgili sorunlardan bahsederken, bir katılımcı ise öğretim üyelerinin yetersizliğini vurgulamaktadır. Katılımcı DR9 “Bizim eğitim sistemimizin eksikliği olarak söyleyebileceğim matematik eğitiminin yetersizliği olabilir. Ekonometri çok büyük bir ihtiyaç olduğu halde bu konuyu yeterince öğrenemedim. Doktora da ana mikro ve makro derslerinin sözel anlatımdan matematiksel anlatıma geçmesi ve ekonometriden destek alması gerekirdi diye düşünüyorum. Ancak burada hocaların değil eğitim sistemimizin yetersizliği var. Belli bir düzey matematik-ekonometri altyapısı olmadan üstüne makro- mikro gibi temel dersleri koyamazsın ve derinlemesine öğrenemezsin" şeklinde görüşünü belirtmektedir.

Üçüncü alt tema olan "maddi kaynak bulamama" araştırma, konferans ve eğitim gibi bilimsel faaliyetler için kaynak bulamamakla ilgilidir. Temayla ilgili bazı katılımcıların ifadeleri şöyledir:

"Araştırmaları gerçekleştirmek amacıyla projelere kaynak bulmak konusunda zaman zaman sorunlar yaşayabiliyoruz" (DR3).

"Bir diğer sorunum, alanım ile ilgili eğitimlere katılmak istememe rağmen, doktora öğrencileri için herhangi bir destek sağlanmaması ve dolayısiyla maddi nedenlerden dolayı bu eğitimlere katılamamam" (DR 23).

Tez için veri ve kaynak bulamama sorunu alt temasında DR8 kodlu katılımcı, "Birçok zorlukla karşılaştım aslında diğer doktora öğrencileri gibi. Bunların en başında tezim ile ilgili materyale ulaşmak geliyordu. Bunun için bir proje gerekliydi" şeklinde görüşlerini belirtmiştir. $\mathrm{Bu}$ alt temalardaki sorunların dişında burs olmaması, mobbinge maruz kalmak, akademik araştırmalara katılamamak ve kütüphanelerin açık olduğu sürelerin yeterli olmaması gibi sorunlar azda olsa dile getirilmiștir.
Yaşamda Karşılaşılan Sorunlar

Doktora yapan kişilerin en çok vurguladıkları sorun "maddi sorunlar" alt temasinda yer almaktadır. Daha sonra "iş yaşam dengesi sorunları", "eleștiriler" ve "askerlik sorunu" alt temaları gelmektedir.

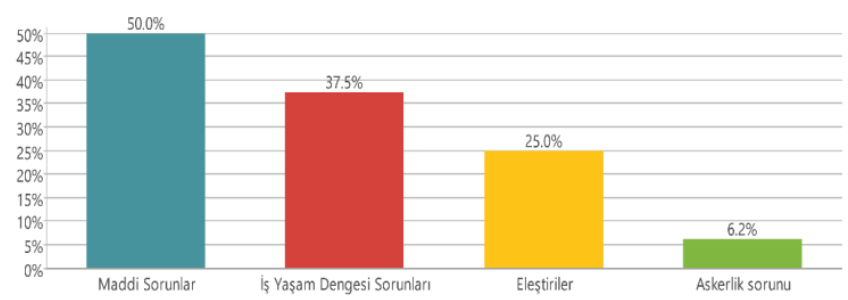

Şekil 11: Yaşamda Karşılaşılan Sorunlar Alt Temaları (\%)

Maddi sorunlar, akademik sorunlar kısmında belirtilen akademik kadroda olmama konusu ile ilgili görülebilir. Bazı katılımcılar açısından maddi sorunların önemli noktalara ulaştığ anlaşılmaktadır. Örneğin DR15 kodlu katılımcı "Finansal açıdan bağımsız olmadığım için çevresel baskılar ve bazen temel ihtiyaçlar için bile ekonomik açıdan yaşanan yetersizlikler doktora eğitimimi olumsuz etkiliyor" ifadeleri ile temel ihtiyaçlarını bile karşılayamadığını belirtmektedir. DR17 kodlu katılımcı ise, "Yoğun bir biçimde gelecek kaygısı yaşıyorum ve gelirimle orantılı olarak sürekli bir biçimde planlarımı ertelemek durumunda kaliyorum" ifadeleri ile sürekli gelecek kaygısı yaşadığını ve plan yapamadığını vurgulamaktadır.

İș ve yaşam dengesi ile ilgili sorunlar ise ikinci sırada gelmektedir. DR2 kodlu katılımcl, "En büyük problemim kesinlikle bazı şeylere zaman ayırmak. Kendime, aileme, eşime... Başka bir işte çalışırken doktora yapmak gerçekten zor. Enerjimi nereye ayıracağımı bazen bilemiyorum. Hayatım sürekli plan yaparak geçiyor. Eşim de (bana her zaman destek olmakla birlikte) hakl olarak bazen bu durumdan çok sikıliyor" ifadeleriyle durumunu anlatmaktadır.

DR10 kodlu katılımcı ise, "Kolay bir süreç olmadığı için birtakım sorunlar oluyor. Așırı yaşamsal problemler olmasa bile sosyalliği, kendinize ve çevrenize olan zamanı kısmak zorunda kalabiliyorsunuz. Bulunduğumuz ortamla, kişilerle ilgili herhangi bir sorun 


\section{B. SEÇER}

olduğunda da mümkün olduğunca çözüm üretme çabasında olunmalı diye düşünüyorum. Düzelmediği takdirde de sorunu büyütmeme tarafinda duruyorum. Her koşulda çalışmaya devam edebilme tecrübesini ediniyorum" şeklinde ifade etmektedir.

Dışarıdan doktora eğitimine devam eden katılımcılar çevrelerinde eleştirilerle karşılaștıklarını ifade etmektedirler. Aslında bu eleştirilerin başka bir alt temanın içeriği olan maddi sorunlardan kaynaklanan eleştiriler olduğu görülmektedir. Örneğin DR8 kodlu katılımcl, "Doktora başlangıcından itibaren ailem ve bu camia dıșındaki arkadaşlarım gösterilen yoğun eforun karşılıksız kaldı̆̆ını düşünerek "neden hala bu eziyete katlanıyorsun anlamiyorum" yorumlarında bulunmuşlardır. $\mathrm{Bu}$ süreçte kendimi anlatmakta bir hayli zorlanıp artık anlatmamaya başladım. Bunun en büyük nedeni tabiki maddi kaynak olmayışıdı" şeklinde yapılan eleștirileri dile getirmektedir.

Bazı katılımcılar ise doktora eğitimi süresince aile, akraba ve arkadaşlar tarafından yapılan eleştiriler nedeniyle yaşadıkları stres düzeyinin arttığını vurgulamaktadır. Örneğin DR13 kodlu katılımcl, "Öte yandan bu süreç boyunca pek çok şeyden ciddi fedakarlıklar yapmam ve "yeter artık, bu çalışmayla nerelere gelmiştin, ne zaman son bulacak bu durum" gibi pek çok kırıcı söze alıșmam gerekiyor. Bu sürecin stresi zaten sağlık durumumu çok etkiliyor. Her şikayetimin altından stres faktörü çıklyor. İşin bir de manevi boyutu var ki; bence bu yolu seçmiş birinin kesinlikle psikolojik destek alması gerekiyor" şeklinde görüşlerini ifade etmektedir. Ayrıca destek aldığını belirtmektedir.

\section{Doktora Eğitimine Verilen Değer}

Dıșarıdan doktora eğitimini sürdürenlere doktora eğitimine verilen değer konusunda düşünceleri sorulmuştur. Kodlamalar onbir alt temada sınıflandırılmıştır. En fazla kodlama doktora eğitimine değer verilmediği temasında bulunmaktadır (Şekil 12).

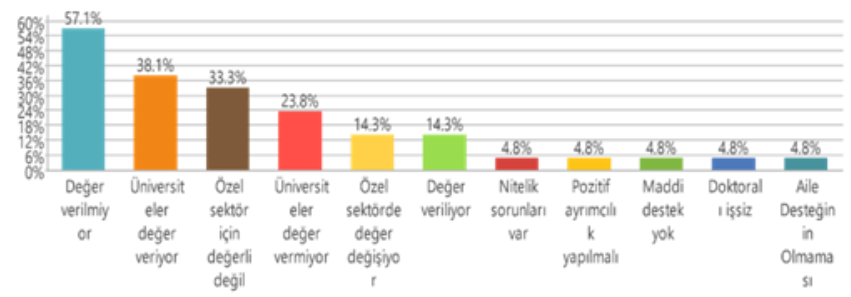

Şekil 12: Doktora Eğitimine Verilen Değer Alt Temaları (\%)

Doktora eğitiminin toplum tarafından bilinmediği ve toplumun başarıyı sadece gelir düzeyi ile değerlendirdiği yönünde değerlendirmeler yapılmaktadır. Örneğin DR8 kodlu katılımcl, "Toplumda sonunda bir kadroya girdiysen değer verildiğini düşünüyorum. Ancak kadrosuz sadece olduğu zaman projeler olmadığı zaman karşılıksız çalıştığınız zaman toplum size pek değer vermiyor" şeklinde düşüncelerini belirtmektedir.

İkinci alt tema doktora eğitimine üniversitelerin değer verdiğini içermektedir. $\mathrm{Bu}$ durum üniversitelerde öğretim üyesi olabilmek için doktor unvanı almak gerekli olduğundan normal karşılanmalıdır. Bazı katılımcıların "üniversiteler değer veriyor" alt teması ile ilgili ifadeleri şöyledir:

DR19 “Üniversiteler ve özellikle son yıllarda devlet tarafindan ise lisans üstü eğitim giderek daha fazla klymet bulmakta; bu durum sevindirici" șeklinde düşüncelerini belirtirken, DR21 "Üniversiteler doktora eğitiminin uluslararası değeri konusunda bilinçli ve doktora eğitimi almış yetişmiş insan kaynağının arttırılması anlamında çaba göstermektedirler" ifadesiyle üniversiteleri vurgulamaktadır.

Üçüncü alt tema doktora eğitimi "özel sektör için değerli değil" şeklindedir. Bu alt temada doktora eğitiminden sonra işletmelerin kişinin istekleri karşılayamaması ve işten ayrılma olasılığından bahsedilmiştir. Ayrıca daha çok tecrübeli eleman arandığı vurgulanmaktadır.

Dördüncü alt tema doktora eğitimine "üniversiteler değer vermiyor" şeklindedir. Daha önce "üniversiteler değer veriyor" alt teması oluşturulmuştu. $\mathrm{Bu}$ alt temada farklılaşan noktalar değer vermeme konusunun temelinde üniversitenin doktora 
öğrencilerini geçici işgücü olarak görmesi, intihal, danışmanların görevlerini iş yoğunluğu nedeniyle yeterli düzeyde gerçekleştirememeleri gibi sorunlardır. Katılımcl DR8 "Üniversiteler ise çoğunlukla geçici iş gücü olarak görüyor bence. Bu insanların hepsine kadro veremeyeceklerini onlar da bizde biliyoruz" şeklinde görüşünü ifade etmektedir.

Beşinci alt tema "özel sektörde doktora eğitimine verilen değerin değişkenlik gösterdiğini" açıklamaktadır. Örneğin DR7 kodlu katılımcl, "İşletmelerin doktora eğitimine bakış açıları işletme çeșidine bağlı olarak değişiyor. Ar-Ge çalışmalarına ağırlık veren işletmeler için doktora eğitimi çok değerli olabiliyor" DR22 kodlu katılımcı, "İşletmelerde de eğitimli insanların oranına bağlı olarak değer algısı değișebilmekte. Ulusal ve uluslararası işletmelerde doktora eğitimine daha fazla değer addedilirken, yerel işletmelerde bu denli yüksek bir değer algısı oluşmayabiliyor" şeklinde düşüncelerini dile getirmektedir.

Altıncı alt temada ise doktora eğitimine değer verildiği ile ilgili düşünceler aktarılmaktadır. Örneğin DR11 kodlu katılımcı, "Özellikle sosyal bilimler alaninda "Doktor" unvanina sahip kişiler toplumda zaman zaman "Tıp Doktoru" ile karıștırılsa da iş hayatından bu unvana sahip olmak, özellikle de sahip olduğunuz unvanla ilgili bir alanda çalışlyor olmak, tabi ki çok önemli bir prestij ve saygınlığa sahip olmanıza neden olmaktadır. Ayrıca, üst düzey bir yönetici iseniz hem uhdenizde çalışan kişilerce hem de ilişkide olduğunuz iş çevrenizce sözünüze çok ciddi bir ssekilde itibar edilmesine katkı sağlamaktadır" ifadelerle alınan eğitim ile ilgili çalışıyorsanız ve üst düzey yöneticiyseniz değer verildiğini belirtmektedir.

Bunlar dışında çok az kodlama yapılan "nitelik sorunları var", "pozitif ayrımcılık yapılmalı", "maddi destek yok", "doktoralı işsiz" ve "aile desteğinin olmaması" şeklinde alt temalar bulunmaktadır. "Doktoralı işsiz" alt temasında DR2 kodlu katılımcl, "Nitelikli insan gücümüzü artırmak adına doktora mezunu kişilerin önemli olduğunu düşünüyorum. Bu noktada diğer bir önemli hususun da doktora sonrası akademik hayata atılma konusunda olduğunu söyleyebilirim. Çünkü doktorasını bitiren mezunlara üniversitelerde iş olanağı sağlanmadığı için bu kişileri kaderlerine terk ediyoruz. Bu da son günlerde popülerlik kazanan bir terimi akla getiriyor "doktoralı işsiz"..." şeklinde görüşlerini belirtmiştir. Doktora eğitimini tamamlayan kişilerin ne kadarının, hangi işlerde çalıştığının izlenmesi önemli bir konudur. Genel olarak doktoralı işsizlik şeklinde bir eğilimin olup olmadığı belirlenebilir.

\section{TARTIŞMA}

Araştırma ile akademi dışından doktora yapan bireylerin doktora sürecini nasıl deneyimledikleri ve süreçte nasıl hissettikleri incelenmektedir. Öncelikle katılımcıların büyük çoğunluğunun hedefi akademisyen olmaktır. Bu nedenle doktora eğitimi aldıklarını belirtmekte ve doktora eğitimini kariyer hedefleri ile uyumlu görmektedirler. De Grande vd. (2014), sosyal bilimler alanında doktora yapanların özel sektörde kariyeri daha az tercih ettiklerini belirlemiştir. Araştırma örnekleminin büyük çoğunluğunun sosyal bilimler alanında doktora eğitimi görmesi ve akademik kariyeri tercih etmesi De Grande vd.'nin bulguları ile uyum göstermektedir. Ayrıca katılımcılar kendilerini geliştirmek için doktora yaptıklarını da belirtmektedir. Bu tema altında özel sektör için kendini geliştirme konusundan söz edilmektedir.

Doktora eğitiminin kişilere yaptığı katkılar eğitime devam etme konusunda önem taşımaktadır. Bu katkılar en fazla "bilgi düzeyinin artması", "analiz becerilerinin artması", "farklı bakış açıları kazanmak" alt temalarında toplanmıştır. En fazla vurgulanan alt temalar doktora eğitiminin amaçları ile paralellik göstermektedir. "Doktora programı, öğrenciye bağımsız araștırma yapma, bilimsel problemleri, verileri geniş ve derin bir bakış açısı ile irdeleyerek yorum yapma, analiz etme ve yeni sentezlere ulaşmak için gerekli becerileri kazandırır" tanımında görüleceği üzere analiz, yeni sentezler yapma becerileri 


\section{B. SEÇER}

vurgulanmaktadır. Böylece doktora öğrencilerinin program amaçlarını doğru algıladıkları belirtilebilir.

Doktora tezinin kariyer ve iş bulmaya etkisi de doktora eğitimine yönelmeyi sağlayan bir değişken olarak görülebilir. Katılımcıların çoğunluğu akademik kariyer hedefledikleri için doktora tezlerinin akademik kariyerlerini olumlu etkileyeceğini düşünmektedir. Benzer şekilde Parada ve Peacock (2015), 12 Avrupa ülkesindeki doktora adaylarından oluşan örneklemde doktora tezi konusunun olmasa da, genel olarak doktora eğitiminin akademik alanda iș imkânlarını arttırdığının düşünüldüğünü tespit etmiştir.

Doktora eğitimi sürecinde sosyalleşmenin önemine dikkat çekilmiştir. Doktora öğrencilerinin sosyalleşmeleri alandaki öğretim üyeleri, danışmanlar ve diğer öğrenciler ile kurdukları ilişkiler ve bilimsel etkinliklere katılım ile gerçekleşmektedir. Bu bağlamda doktora öğrencileri danıșmanlarını destekleyici bulduklarını belirtmektedir. Parada ve Peacock (2015), Avrupa ülkelerinde doktora yapanlardan oluşan geniş bir örneklemde çoğunluğun danışmanlarını destekleyici bulduklarını tespit etmiştir.

Katılımcıların büyük çoğunluğu bilimsel yayınları takip ettiklerini ve bilimsel faaliyetlere katılmaya çalıştıklarını belirtmiştir. Ancak yarıya yakını sosyal ağ geliştiremediğini ve bir kısmı da kendini alanın parçası olarak hissetmediğini ifade etmektedir. Bazıları ise kendilerine farklı davranıldığını ifade etmektedir. Doktora öğrencilerinin kendilerini eğitim gördükleri alanın parçası olarak hissetmeleri yayın ve eğitim faaliyetlerine katılma, diğer akademisyenler tarafından önemli kabul edilme ve öğrenme ile katılım sonucunda gerçekleşmektedir (Emmioğlu vd.,2017). Bu koşulların örneklemdeki doktora öğrencileri için ne kadar gerçekleştiği tartışmalıdır.

Doktora öğrencilerinin akademik alanda ve yaşamlarında karşılaştıkları sorunların doktora eğitiminin yarıda kalmasına veya mezuniyet süresinin uzamasına neden olmasından dolayı önemli olduğu ileri sürülmektedir. Daha önce katılımcıların çoğunun akademik kariyer beklentisi ile doktora eğitimi yaptıkları belirtilmiști. Dolayısıyla kadrolarının bulunmamasını akademik anlamda önemli bir sorun olarak ifade etmektedirler ve buna bağlı başka sorunların da ortaya çıktığı anlaşılmaktadır.

Ayrıca eğitim ile ilgili yetersizlikler de bir sorun olarak dile getirilmiştir. Yazında benzer sorunların daha önce de açıklandığı görülmektedir. Örneğin Sayan ve Aksu (2005) kütüphanelerden yararlanma zorlukları, Özmen ve Güç (2013) ise derslerle ilgili sorunlar olduğunu tespit etmişlerdir. Araştırmalar için maddi kaynak bulamamak ise yine kadro olmaması ile bağlantılı ve doktoranın bitirilememesi veya daha uzun sürede bitirilmesi ile ilgili olabilecek bir sorundur. Ayrıca tez için kaynak ve veri bulma sorunları da belirtilmiştir.

Katılımcılar yaşamları ile ilgili önemli sorunlarından biri kadro olmaması ile alakalı olduğunu söyleyebileceğimiz maddi sorunlardır. Bu alt temada temel ihtiyaçlarını karşılamakta zorluk yaşayanlar olduğu belirlenmiştir. Sayan ve Aksu 2005 yllındaki çalışmalarında benzer şekilde ekonomik zorlukları önemli bir sorun olarak tespit etmiştir. Doktora eğitiminin iş yaşam dengesi açısından sorunlar yarattığı da katılımcılar tarafından vurgulanmıştır. Özmen ve Güç (2013), araştırmalarında doktora eğitimi sürecinde özel hayattan fedakarlık yapılmak durumunda kalındığını belirlemesi iş yaşam dengesi sorunlarına işaret etmektedir.

Akademi dışından doktora eğitimine devam edenlere çevrelerinin yaptıkları eleştiriler bazı katılımcllar tarafından sorun olarak vurgulanmıștır. Yazında daha önce rastlamadığımız bu sorun yine katılımcıların akademik hedefleri olması, ancak kadroya sahip olmamaları ile ilgili görülebilir. Doktora eğitiminin uzun yıllar çalışmayı gerektirmesi ve karşılığında bir maddi karşılığın olmadığının sosyal çevre tarafından düşünülmesi bu eleştirilere neden olmaktadır. 
Son olarak katılımcılar büyük ölçüde doktora eğitimine toplumun ve işletmelerin önem vermediğini, sadece üniversitelerin önem verdiğini düşünmektedir. Bazı katılımcılar doktora eğitimine araştırma geliştirme odaklı işletmelerin ilgi gösterdiğini belirtmişlerdir. $\mathrm{Bu}$ bağlamda "doktoralı işsiz" kavramından bahsedildiği görülmektedir. Katılımcıların çoğunluğunun akademik kariyer beklentisinde olması ve henüz kadroya girememelerinin, hatta bazıların çok sayıda ilana başvurup başarılı olamamasının bu durumla ilgili olduğu ileri sürülebilir.

\section{SONUÇ}

Akademi dışından doktora yapan kişilerin motivasyonları, deneyimleri ve yaşadıkları sorunlar fazla araştırılmayan bir konu olarak karşımıza çıkmaktadır. Ülkelerin çeşitli nedenlerle son yıllarda doktora eğitimine verdikleri önemin arttığı anlaşılmaktadır. Ülkemizde yeni üretim yapısının gerektirdiği araştırmacı işgücü ile yeni açılan üniversitelerin öğretim üyesi ihtiyacının doktora mezunlarına olan talebi arttırdığ belirtilmektedir.

Doktora eğitimi geleneksel olarak akademik kariyere girişin ön şartı olarak görülmektedir.
Ancak günümüzde doktora mezunlarının akademi dışında da istihdam edilme olanaklarının bulunduğu görülmektedir. Çalışmada akademisyen olmadığı halde doktora eğitimi yapanların temel motivasyonlarının akademik kariyer olduğu belirlenmiştir. Ayrıca doktora eğitimleri sürecinde sosyalleșme konusunda sorunlarla karşılaşabildikleri ve kendilerini kısmen çalıştıkları alanın parçası olarak hissettikleri belirlenmiştir.

Akademi dışından doktora eğitimine devam eden kişilerin yaşadıkları temel sorunun kadrolarının olmamasından kaynaklandığı belirlenmiştir. Buna bağlı olarak maddi sorunlar, araştırma için kaynak bulamama ve çevrenin eleştirileri gibi sorunlarla karşılaşıldığı tespit edilmiştir. Ayrıca iş yaşam dengesi sorunları dikkat çekmektedir.

Araştırmanın kısıtı örneklemin çoğunluğunun sosyal bilimler alanında eğitim görmesidir. Yazında ve çalışmada sosyal bilimler alanında doktora eğitimi görenlerin akademik kariyeri tercih ettikleri tespit edilmiştir. Mühendislik gibi işgücü piyasasında işsizlik riski daha düşük olan alanlarda akademi dışından doktora yapanların deneyimleri farklı boyutlarda gerçekleşebilir.

\section{KAYNAKÇA}

Akbulut H., Şahin Ç., Çepni S., (2013), “Doktora Tez Sürecinde Karşılașılan Problemlerin Belirlenmesi: Eğitim Fakültesi Örneği", Dicle Üniversitesi Ziya Gökalp Eğitim Fakültesi Dergisi, C:20, 50-69.

Akturan, U., Esen, A. (2013). Fenomenoloji. Baş T. ve Akturan, U. (Der.) Nitel araştırma yöntemleri (s.83-98). Ankara: Seçkin.

Baş G., (2013), “Öğretmenlerin Lisansüstü Eğitimden Beklentileri: Nitel Bir Araştırma (Niğde İli Örneği), Yükseköğretim Dergisi, 2013;3(2):61-69.

Bernsteın B., Evans B., Fyffe J., Halaı N., Hall F. L., Jensen H. S., Marsh H., Ortega S. (2014), "The Continuing Evolution of The Research
Doctorate", Globalization and Its Impacts on the Quality of PhD Education, (Eds. B. Nerad, B. Evans), Sense Publishers, Netherlands, 5-30.

Brallsford I., (2010), "Motives and aspirations for doctoral study: Career, personal, and interpersonal factors in the decision to embark on a history Ph.D.", International Journal of Doctoral Studies, 5, 15-27.

Churchill H., Sanders T. (2007), Getting Your $\mathrm{PhD}$ A Practical Insider's Guide, Sage Publications.

De Grande H., De Boyser K., Vandevelde K., Rossem V., (2014), "From academia to industry: are doctorate holders ready?", 


\section{B. SEÇER}

Journal of the Knowledge Economy, (5):538561.

Emmioğlu S. E., Mcalpıne L., Amundsen C., (2017), "Doctoral Students' Experiences of Feelıng (Or Not) Like An Academic", International Journal of Doctoral Studies, 1273-90.

Gardner, S. K., Gopaul, B., (2012), "The parttime doctoral student experience", International Journal of Doctoral Studies, 7, 63-78.

Gill T., Hoppe U., (2009). "The business professional doctorate as an informing channel: A survey and analysis", International Journal of Doctoral Studies, 4, 27-57.

Golde C. M., (2005), "The Role of the Department and Discipline in Doctoral Student Attrition: Lessons from Four Departments", The Journal of Higher Education, 76:6, 669700 .

Günay D., (2018), “Türkiye'de Lisansüstü Eğitim ve Lisansüstü Eğitime Felsefi Bir Bakış", Üniversite Araștırmaları Dergisi, Ağustos 2018, Cilt 1, Sayı 2, Sayfa: 71-88.

https://yuzikibinbursu.yok.gov.tr/Sayfalar/H aberDuyuru/100-2000-doktora-projesinedir.aspx, (06.06.2020).

James, N. Ve Hugh, B. (2016), Online Interviewing, (Ed. D. Silverman), Qualitative Research (ss.245-260). London: Sage.

Karadağ E., Danışman Ş., Dulay S., Öztekin Bayır Ö., Tekel E., (2018), "Eğitim fakültesi araştırma görevlilerinin zorlu akademik yolculukları: Doktora tez süreci", Yükseköğretim Dergisi, 8(1), 103-112.

Keçeli S. A., Duymaz F. Z., (2017), "Lisansüstü Eğitimin Anket Sonuçları İle Değerlendirilmesi: Kocaeli Üniversitesi Deneyimi”, Kocaeli Üniversitesi Sağlık Bilimleri Dergisi Eylül, Cilt 3, Sayı 3, s.24-27.

Nyquist, J. D., Manning, L., Wulff, D. H., Austın, A. E., Sprague, J., Fraser, P. K., Woodford, B. (1999), "On the road to becoming a professor", Change, 31(3), 18-27.
Özmen Z. M., Aydın Güç F., (2013). "Doktora eğitimi ile ilgili yaşanan zorluklar ve baş etme stratejileri: Durum çalışması", Yükseköğretim ve Bilim Dergisi, 3(3), 214-219.

Parada F., Peacock J., (2015), “The Quality of Doctoral Training and Employability of Doctorate Holders: the Views of Doctoral Candidates and Junior Researchers", The European Higher Education Area: between critical reflections and future policies. (Eds. Curaj A., Matei L., Pricopie R., Salmi J., Scott P.), Berlin: Springer, 593-612.

Sayan Y., Aksu H. H., (2005), "Akademik Personel Olmayan Lisansüstü Eğitim Yapan Bireylerin Karșılaștıkları Sorunlar Üzerine Bir Çalışma: Dokuz Eylül Üniversitesi, Balıkesir Üniversitesi Durum Belirlemesi”, Dokuz Eylül Üniversitesi Buca Eğitim Fakültesi Dergisi, (Özel Sayı 1), 59-66.

Sever I., Ersoy A., (2017), “Araștırma Görevlilerinin Gözünden Danışmanlık ve Doktora Süreçleri", Eğitim Bilimleri Araştırmaları Dergisi, (7:1), 183-202.

Sevinç B., (2001), “Türkiye'de lisansüstü eğitim uygulamaları, sorunlar ve uygulamalar", Dokuz Eylül Üniversitesi Eğitim Fakültesi Dergisi, 34(1), 25-40.

Sezgin F. (2002), Araştırma görevlilerinin yetiştirilmesinde tez danışmanı öğretim üyelerinin yetiştiricilik rolleri. Yüksek Lisans Tezi, Gazi Üniversitesi Eğitim Bilimleri Enstitüsü: Ankara.

Weidman J. C., (2010), Doctoral student socialization for research, On becoming a scholar. Socialization and development in doctoral education. (Eds. S. K. Gardner, P. Mendoza) Virginia: Stylus Publishing, LLC.

Yıldırım, A., Şimşek, H. (2005). Sosyal Bilimlerde Nitel Araştırma Yöntemleri (5.Baskı). Ankara: Seçkin Yayıncılık 


\section{Ek 1: Ana ve Alt Temaların Kod Matrisi}

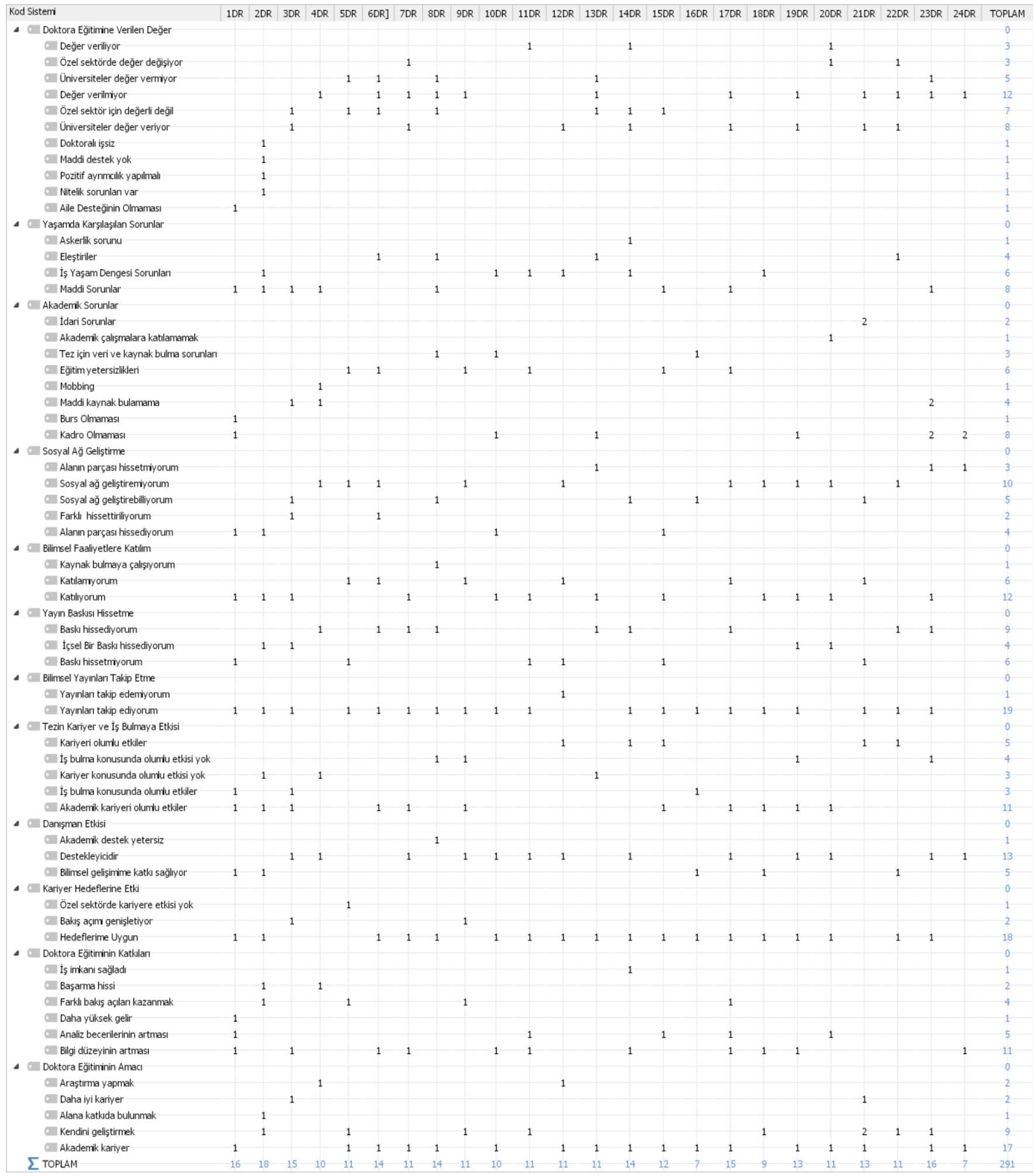

